\title{
Analyzing the Local Spread of Ips typographus (L.) (Coleoptera: Curculionidae, Scolytinae) by Pheromone Catches in Turkey's Hatila Valley National Park
}

\author{
Hazan Alkan Akinci ${ }^{1 *}$, Yaşar Aksu² \\ ${ }^{1}$ Department of Forestry Engineering, Faculty of Forestry, Artvin Çoruh University, 08000, Artvin, Turkey \\ ${ }^{2}$ Artvin Regional Directorate of Forestry, 08000, Artvin, Turkey
}

Received: 22 May 2017

Accepted: 10 August 2017

\begin{abstract}
Ips typographus is one of the most destructive pests of Oriental spruce (Picea orientalis (L.) Link.) forests in Turkey. During the outbreak years it killed millions of spruce trees. Today, Oriental spruce forests, including the Hatila Valley National Park area, shelter an endemic population of the beetle. Pheromone trapping against I. typographus has been employed in 1989 in addition to mechanical control measures. In this study, we employed a total of 105 pheromone traps to investigate the endemic population of the beetle in Hatila Valley National Park forests in Artvin. We tried to analyze local spread of the beetle by means of inverse distance weighting (IDW) and statistical analyses. Pure spruce stands and stands with larger diameter trees hosted higher numbers of I. typographus. IDW showed locations that may have higher beetle populations in the next generation. There were a total of 33 pheromone traps at these locations. The average number of beetles caught in these traps was 2 and 1.3 times higher than the average number of beetles in all traps and traps that were employed in pure stands, respectively. They caught $63.3 \%$ of the captured beetles. IDW maps can provide useful data for monitoring with a limited number of monitoring units.
\end{abstract}

Keywords: Ips typographus, Hatila Valley National Park, pheromone trapping, spatial interpolation, IDW

\section{Introduction}

Oriental spruce (Picea orientalis (L.) Link.) are distributed throughout the eastern Black Sea Mountains in Turkey. It is a native species. Oriental spruce forests

*e-mail: hazan.akinci@artvin.edu.tr have an above-and-beyond function of supplying water, soil protection, and preventing natural destruction. Some traditional utilization habits like frequent human transportation during summer to highlands through these forests, animal grazing, wounding trees, and dispersed settlements of forest villages cause fragmented forests in the region. These fragmented structures of the spruce forests have eased bark beetle epidemics. Quantitative 
and qualitative losses have been faced during epidemics [1].

Among bark beetles that infest the bark of trees, the spruce bark beetle Ips typographus (L.) (Coleoptera: Curculionidae, Scolytinae) is the most damaging species that attacks spruce trees. It can build up large populations during outbreaks and kill millions of healthy trees in large stands [2-6]. It was discovered in 1984 in spruce forests of Artvin, and has killed millions of Oriental spruce trees to date [3, 7-8]. Today, it has an endemic population in Artvin except for a 15-ha area in Şavşat Province, $80 \mathrm{~km}$ from Artvin.

The aim of managing bark beetles is to minimize attacks on living trees [2]. Basic management practices are salvage that involves clearing windthrows, sanitation felling of newly infested standing trees before the beetles devastate trees and have an economically significant impact on them, and mass trapping of attacking beetles by trap trees and pheromone traps [2-3]. Pheromone traps have long been used for monitoring bark beetle populations. Pheromone traps that are baited with insect pheromones attract and trap flying beetles before landing on a new host and starting a new brood system. Monitoring by pheromone traps allows for the collection of data on flight periods, and the number of captured beetles that can vary between years depends on the density of the beetle population [9-10]. The prime aim of this kind of monitoring is to classify the beetle population over or under the risk threshold [11].

In Turkey, pheromone trapping against I. typographus has been employed since 1989 in addition to mechanical control measures such as salvage and sanitation felling in order to control the population of the beetles. Timbers have been harvested at windthrow areas in accordance with salvage measures. Sanitation felling of infested trees was performed before the adult beetles emerge [3]. The former practice is recommended within two years after the windthrow [12-13]. The latter is to be applied soon after a beetle infestation $[12,14]$.

During field surveys in 1989, it was recorded that I. typographus was established in Oriental spruce forests of Artvin, including Hatila Valley National Park. Storms in 1999 and 2000 caused a total of $20,000 \mathrm{~m}^{3}$ of windthrows in the park area. Severe outbreaks followed these windthrows [3]. Furthermore, Okland et al. [5] and Netherer et al. [15] affirmed in their findings that windthrows were responsible for triggering beetle outbreaks. The authors further underlined the decrease in tree resistance and the increase in beetle population that is needed to overcome tree resistance and kill healthy trees in windthrow areas $[5,15]$.

Windthrows and bark beetle disturbances are left untouched in national parks in order to conserve natural processes. But concerns about these windthrows and bark beetle disturbances in protected areas have also been discussed [12, 16-17]. It is known that salvage has a positive effect on lowering the risk of a beetle outbreak [12]. According to the Turkish National Parks Act [18], production of forestry products, hunting, and grazing cannot be done in a national park with the purpose of maintaining ecological integrity. However, the concern is that the emerging beetles may spread to neighboring managed forests outside the national park, in which case a beetle outbreak might kill trees on a large scale in the park. Economic losses led foresters to cut a total of $260,012 \mathrm{~m}^{3}$ of spruce trees in a 7,476 ha outbreak area in the park in 2003-09. The average number of beetles caught in traps at the park was 8,967 in 2004. Several traps in the outbreak area captured about 17,000 beetles on average in 2004 . The average was about 1,000 beetles in 2009. After 2009, monitoring by pheromone traps is ongoing in the national park area [3]. Pheromone traps, when employed under endemic conditions, offer excellent information for monitoring the population of $I$. typographus [19].

In 2015 and 2016 storms caused 20,000-30,000 $\mathrm{m}^{3}$ windthrows at different sites of the national park area. The time period in which windthrows will have the highest beetle population depends on the desiccation of the bark. The highest $I$. typographus population emerges in the second summer after a storm at lower altitudes and in the third summer at higher altitudes. Beetle attacks occur on windthrows rather than stumps. Infestation is higher at larger trunks than thinner trees [2, 5]. It is anticipated that there will probably be a population increase in the windthrows and surrounding stands mentioned above in the following years in Hatila Valley National Park. Therefore, there is a need to develop practical tools for effective monitoring of I. typographus.

In this study, we investigated the local spread of endemic population of I. typographus by pheromone traps in Hatila Valley National Park in Turkey. We estimated the possible areas that may have a relatively higher beetle population in the next developing period using IDW and discussed the characteristics of these stands. We actually gave estimates that can be practically used by local foresters in monitoring a beetle population that is a laborintensive and time-consuming practice.

\section{Materials and Methods}

\section{Study Area: Hatila Valey National Park}

Hatila Valley National Park was established in 1994 as one of the protected areas in Artvin Province in northeastern Turkey (Fig. 1). Total area of the national park is 17,104 ha. Of the national park's area, $74.5 \%$ is forested, $24.5 \%$ belongs to the state, and $1 \%$ is privately owned. Slope increases up to $80-90 \%$ and sometimes more than $100 \%$ along the valley. Also, the park is at 1,150-3,224 $\mathrm{m}$ a.s.l. Local people are beekeepers and stockbreeders. Traditional transhumance activity continues in the region [20].

The park is rich in flora. A total of 1,349 plant taxa, of which 125 are endemics, have been recorded. Oriental spruce mostly forms pure stands and sometimes mixed stands with Pinus sylvestris L., Abies nordmanniana 
(Stev.) Spach. subsp. nordmanniana, Taxus baccata L., and other species at 1,200-2,200 m a.s.1. [20].

\section{Field Survey}

The Ips typographus population was monitored in the park during the flight period of the beetle in 2014 .
A field survey focused on part of the former outbreak area. A total of 835.50 ha of Oriental spruce forests were monitored during the survey. We employed 105 multiple funnel traps baited with Pheroprax (Shell Agrar GmbH \& Co., KG, Germany) in the field.

Pheromone traps were installed at 1,265-2,100 $\mathrm{m}$ a.s.l. in pure and mixed stands of oriental spruce in eastern,

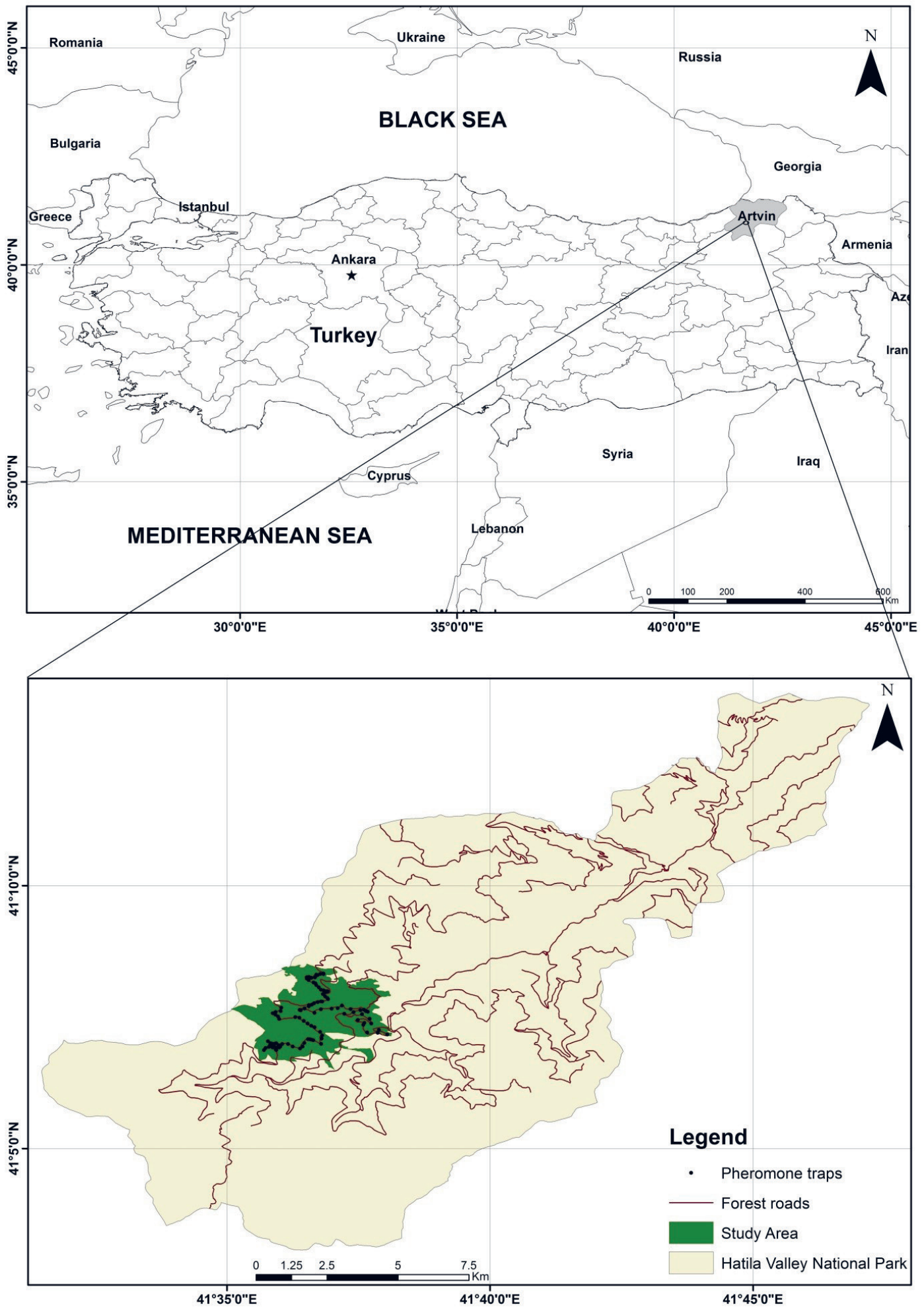

Fig. 1. Map of Turkey, and the position of Hatila Valley National Park and the investigated stands in the park. 
western, northern, and southern aspects. Numbers of pure spruce stands and spruce-dominated mixed stands where the traps were installed were 29 and 76, respectively. There were fir, Scotch pine, beech, chestnut, aspen, hornbeam, birch, oak, and maple in the mixed stands other than spruce. Average slope was 59\%. Traps were baited in late April and a first check was made on May 9. After this day, traps were checked every 15 days until late September. Pheromone dispensers were replaced every four weeks.

\section{Inverse Distance Weighting}

Inverse distance weighting (IDW) is one of the most frequently used methods in spatial interpolation. It is relatively fast and easy to compute, and straightforward to interpret as expressed by Lu and Wong [21]. The IDW method estimates the values of an attribute at unsampled points using a linear combination of values at sampled points weighted by an inverse function of the distance from the point of interest to the sampled points. The assumption is that sampled points closer to the unsampled point are more similar to it than those further away in their values [22]. The weight function $w_{i}$ used in IDW can be expressed as:

$$
w_{i}=\frac{1 / d_{i}^{p}}{\sum_{i=1}^{n} 1 / d_{i}^{p}}
$$

...where $p$ is called power parameter (the most popular choice of $p$ is 2), and $n$ represents the number of sampled points used for the estimation, and $d_{i}$ is the distance from the dispersion points to the interpolation point, given by:

$$
d_{i}=\sqrt{\left(x_{0}-x_{i}\right)^{2}+\left(y_{0}-y_{i}\right)^{2}}
$$

...where $\left(x_{0}, y_{0}\right)$ are the coordinates of the interpolation point and $\left(x_{i}, y_{i}\right)$ are the coordinates of each dispersion point [23].

It is known about I. typographus that, of the local population, $50 \%$ are thought to fly further than $500 \mathrm{~m}$. But sites that have higher risk of I. typographus attack around an existing infestation are within $100 \mathrm{~m}$ [2]. In this sense we chose IDW that estimates values of unsampled points as inverse functions of distance from the sampled points.

\section{Statistical Analyses}

Data were analyzed using IBM SPSS statistics version 19.0. T test was performed to compare the number of beetles caught at pure spruce and spruce-dominated mixed stands. Analysis of variance (ANOVA) was performed to compare the numbers of beetles caught between development stages and aspects. Correlation analysis was carried out between the number of caught beetles, and altitude and slope. SEM values are given with averages.

\section{Results}

A total of 42,055 I. typographus adults were caught in the traps (Table 1). The average number of beetles caught per trap was $401 \pm 33.2(1-1,817)$. The average number of beetles caught at pure spruce and spruce-dominated mixed stands was 622 and 318, respectively.

Possible locations that may have higher beetle populations in the following generation were examined by performing IDW (Fig. 2). There were a total of 33 pheromone traps at these locations (Table 1). These possible locations have orange to red colors in Fig. 2 that are in the fourth, fifth, and sixth IDW classes in Table 1. Of the total number of beetles caught, $63.3 \%$ were caught at these locations. The average number of beetles caught per trap was $807 \pm 49.8$ (466-1,817). Eighteen of these traps were at pure spruce stands and 15 were at mixed stands. The rest of the traps were at locations where IDW showed lower population densities. There were 72 traps and the average number of beetles caught per trap was $214 \pm 17.1$ (1-527) at these sites.

Of the total number of beetles caught at the employed 105 pheromone traps, the numbers of beetles caught at the pure stands were significantly different from those at the mixed stands ( $\mathrm{t}$ test, $\mathrm{t}=4.644, \mathrm{df}=103, \mathrm{p}<0.05$ ). Numbers of beetles caught were significantly different between development stages (ANOVA, $\mathrm{df}=2, \mathrm{~F}=6.144, \mathrm{p}<0.05$ ). Higher catches were performed at stands with trees that had higher diameters. Numbers of beetles caught were not significantly different between aspects. (ANOVA, $\mathrm{df}=7$, $\mathrm{F}=1.085, \mathrm{p}=0.379)$. There was no significant correlation between the numbers of beetle catches and altitude and slope.

\section{Discussion}

The numbers of beetles caught in our study area in pure spruce stands and spruce-dominated mixed stands was both well below the former pheromone catches performed during the I. typographus outbreak in the national park and the risk-damage threshold that is approximately 5,000 beetles per trap as reported by Faccoli and Stergulc [24]. The maximum number of beetles that were caught in

Table 1. Distribution of pheromone traps by IDW classes.

\begin{tabular}{|c|c|c|c|}
\hline $\begin{array}{c}\text { IDW } \\
\text { class }\end{array}$ & $\begin{array}{c}\text { Number of } \\
\text { pheromone } \\
\text { traps }\end{array}$ & $\begin{array}{c}\text { Number of } \\
\text { beetles caught }\end{array}$ & $\begin{array}{c}\text { Average number } \\
\text { of beetles per } \\
\text { trap }\end{array}$ \\
\hline 1 & 43 & 4,937 & 115 \\
\hline 2 & 18 & 5,750 & 319 \\
\hline 3 & 11 & 4,732 & 430 \\
\hline 4 & 13 & 7,630 & 587 \\
\hline 5 & 13 & 10,215 & 786 \\
\hline 6 & 7 & 8,791 & 1,256 \\
\hline
\end{tabular}




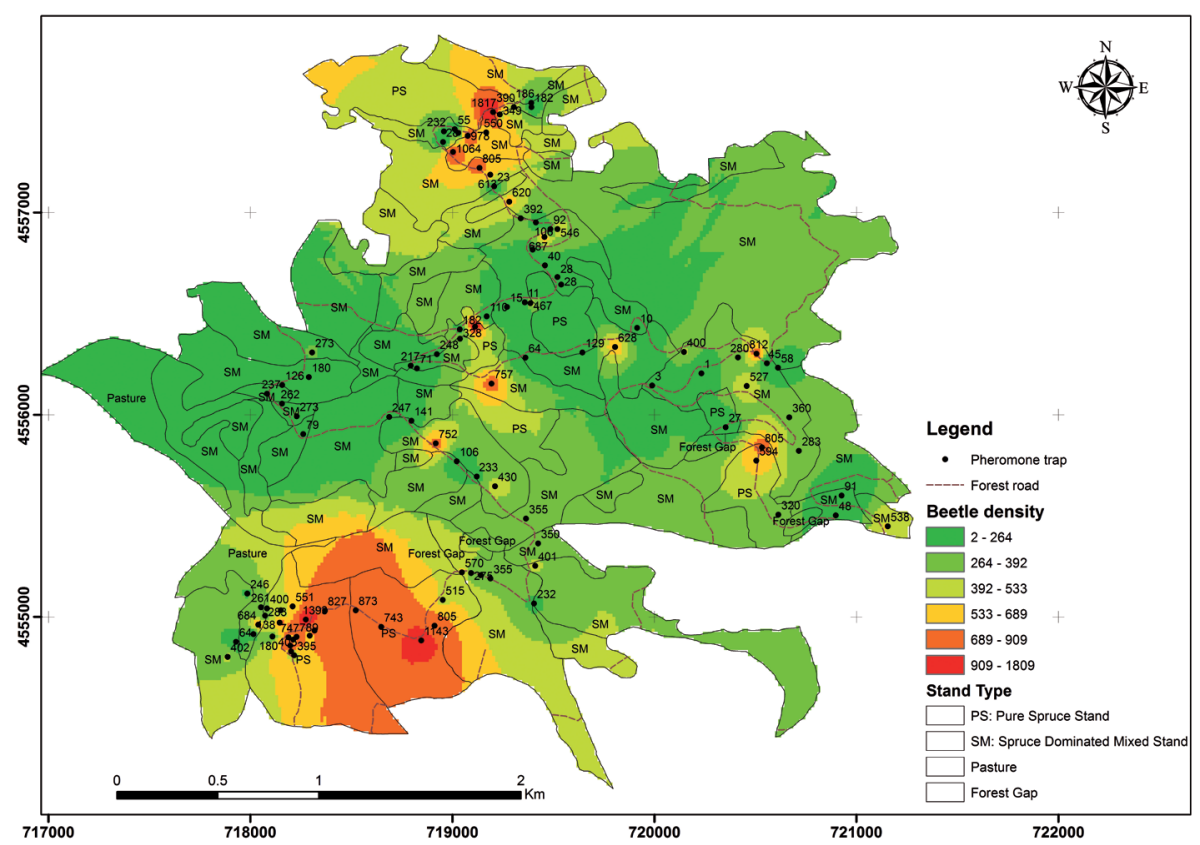

Fig. 2. Beetle density according to IDW.

the traps was also lower than the risk-damage threshold value.

Pheromone traps, when employed under endemic conditions, offer excellent information for monitoring the population of I. typographus [25]. The number of beetles caught in our study truly reflected the beetle population density in the examined stands. In our study, pure spruce stands and stands with larger diameter trees hosted more I. typographus than spruce-dominated mixed stands and stands with thinner diameter trees, respectively. A similar situation was also recorded in earlier works [2, 7]. In the former modelling studies of infestation risk of $I$. typographus in Norway spruce forests [26-27], stand age was expressed to have the greatest effect on infestation risk and increasing the risk of windthrows. Overback and Schmidt [26] explain this effect that by spruce stands being less dense with increasing age, this kind of stand thus becomes warmer than denser stands at younger ages. It is also expressed that these stands may possibly be favorable to I. typographus development [26]. There is an increasing number of windthrows in older stands and this ensures ideal breeding material for I. typographus [27]. Host tree volume per unit area at the stand scale (i.e. $\mathrm{m}^{3}$ of growing stock of spruce per ha) is reported as the most important variable predicting where the risk for new infestation spots is highest [28]. This result is in parallel with our result that shows higher risk in pure spruce stands. I. typographus pheromone catches were not significantly different between aspects, altitude, and slope. Pavel et al. [29] report that in the beginning phase of the outbreak, the majority of infestations occur in stands with lower elevations and in sun-exposed localities. But in the second phase of the outbreak, new infestations were more frequent in trees at higher elevations. Akkuzu and Sarıyıldiz [30-31] found that the number of I. typographus catches was higher at 1,700-2,200 m, which increased with increasing temperature and wind, and decreased with precipitation and moisture in Artvin Oriental spruce forests. Lobinger and Skatulla [32] and Jakus [33] reported that trees in the southern aspect had more attacks. In addition, the number of beetles may differ significantly according to aspect, altitude, and slope parameters when extreme climate conditions exist in a region. Drought is known to favor bark beetle attacks [34], and together with steep slopes decreases host resistance - especially at the southern aspect [35]. Contrarily, in our study scale, extreme climatic conditions did not exist in the studied region, and did not affect beetle dispersal.

\section{Conclusions}

There were a total of 33 pheromone traps that were employed at the locations where IDW gave a higher beetle population. The average numbers of beetles caught in these traps were 2 and 1.3 times higher than the average number of beetles in all traps and traps that were employed in pure stands, respectively. These traps, which are approximately one-third of traps employed in the study area, caught $63.3 \%$ of the captured beetles. For foresters, employing pheromone traps and performing monitoring during the entire growing season is a time-consuming and labor-intensive process besides other forestry operations. Windthrows during 2015 and 2016 winters can be focal points of possible I. typographus outbreak throughout the following years in Hatila Valley National Park. To achieve effective monitoring performed by a limited number of monitoring units, it will be practical to decide about additional control measures against I. typographus in the park area. In this sense, IDW, which 
has a comprehensible and easily applicable mathematical model and is used in various scientific disciplines [36-40], can also be a practical tool for foresters.

\section{References}

1. ALKAN-AKINCI H., ÖZCAN G.E., EROĞLU M. Impacts of site effects on losses of oriental spruce during Dendroctonus micans (Kug.) outbreaks in Turkey. African Journal of Biotechnology, 8 (16), 3934, 2009.

2. WERMELINGER B. Ecology and management of the spruce bark beetle Ips typographus - a review of recent research. Forest Ecology Management, 202, 67, 2004.

3. COŞKUN A.K., AKSU Y., GÖKTÜRK B.Ç. Picea orientalis ormanlarında zarar yapan Ips typographus L, (Coleoptera: Scolytidea)'ın biyolojisi, morfolojisi, yayılışı, zararı, yapılan mücadele çalışmaları ve alınan sonuçlar üzerine araştırmalar. III. Ulusal Karadeniz Ormancılık Kongresi, 1309-1317, 20-22 Mayıs, Artvin, Turkey, 2010.

4. ØKLAND B., KROKENE P., LANGE H. Effects of climate change on the spruce bark beetle. ScienceNordic, 27, 1, 2012.

5. ØKLAND B., NIKOLOV C., KROKENE P., VAKULA J. Transition from windfall- to patch-driven outbreak dynamics of the spruce bark beetle Ips typographus. Forest Ecology and Management, 363, 63, 2016.

6. VEGA F.E., HOFTSTETTER R.W. Bark Beetles, Biology and Ecology of Native and Invasive Species. Elsevier / Academic Press, London, UK. ISBN: 978-0-12-417156-5, 2015.

7. ÖZCAN G.E., EROĞLU M., ALKAN-AKINCI H. Ips typographus (Linnaeus) (Coleoptera: Curculionidae)'un Zarar Düzeyi, Saldırı Yoğunluğu ve Feromon Tuzaklarına Yakalanma Oran1. Türkiye I. Orman Entomolojisi ve Patolojisi Sempozyumu, 21-27, 23-25 Kasım, Antalya, Turkey, 2011.

8. ALKAN-AKINCI H., EROĞLU M. Host partitioning of some bark beetles in oriental spruce stands in ArtvinTurkey. International Caucasian Forestry Symposium, 328334, 24-26 October, Artvin, Turkey, 2013.

9. FACCOLI M., STERGULC F. A practical method for predicting the short-time trend of bivoltine populations of Ips typographus (L.) (Col., Scolytidae). Journal of Applied Entomology, 130 (1), 61, 2006.

10. ÖZCAN G.E., ÇiÇEK O., ENEZ K., YILDIZ M. Evaluation of the counting success of pheromone-baited trap with electronic control unit. Current Science, 111 (1), 192, 2016.

11. WAINHOUSE D. Ecological methods in forest pest management, Oxford University Press, New York, 228, 2005.

12. HAVAŠOVÁ M., FERENČÍK J., JAKUŠ R. Interactions between windthrow, bark beetles and forest management in the Tatra national parks. Forest Ecology and Management, 391, 349, 2017.

13. NIKOLOV C., KONÔPKA B., KAJBA M., GALKO J., KUNCA A., JANSKÝ L. Post-disaster forest management and bark beetle outbreak in Tatra National Park, Slovakia. Mountain Research and Development, 34, 326, 2014.

14. STADELMANN G., BUGMANN H., MEIER F., WERMELINGER B., BIGLER C. Effects of salvage logging and sanitation felling on bark beetle (Ips typographus L.) infestations. Forest Ecology and Management, 305, 273, 2013.

15. NETHERER S., MATTHEWS B., KATZENSTEINER K., BLACKWELL E., HENSCHKE P., HIETZ P., PENNE-
RSTORFER J., ROSNER S., KIKUTA S., SCHUME H., SCHOPF A. Do water limiting conditions predispose Norway spruce to bark beetle attack? New Phytologist, 205, 1128, 2015.

16. MONTANO V., BERTHEAU C., DOLEŽAL P., KRUMBÖCK S., OKROUHLÍK J., STAUFFER C., MOODLEY Y. How differential management strategies affect Ips typographus L. dispersal. Forest Ecology and Management, 360, 195, 2016.

17. THORN S., BÄSSLER C., SVOBODA M., MÜLLER J. Effects of natural disturbances and salvage logging on biodiversity - lessons from the Bohemian Forest. Forest Ecology and Management, 388, 113, 2017.

18. TNPA. Turkish National Parks Act (2873 sayılı Milli Parklar Kanunu). (Web page: http://www.milliparklar.gov.tr/ korunanalanlar/belgeler/2873.pdf) (Date accessed: December, 2016).

19. WESLIEN J., ANNILA E., BAKKE A., BEJER B., EIDMANN H.H., NARVESTAD K., NIKULA A., RAVN H.P. Estimating risks for spruce bark beetle (Ips typographus (L.)) damage using pheromone-baited traps and trees. Scandinavian Journal of Forest Research, 4 (1-4) 87, 1989.

20. ANONYMOUS. Hatila Vadisi Milli Park1, T.C. Orman ve $\mathrm{Su}$ İşleri Bakanlığı. (Web page : http://bolge12.ormansu. gov.tr/12bolge/hatilavadisimilliparki.aspx?sflang=tr). (Date accessed : August, 2016).

21. LU G.Y., WONG D.W. An adaptive inverse-distance weighting spatial interpolation technique. Computers \& Geosciences, 34 (9), 1044, 2008.

22. LI J., HEAP A.D. A Review of Spatial Interpolation Methods for Environmental Scientists. Geoscience Australia, Record 2008/23, 137, 2008.

23. AZPURUA M., DOS RAMOS K. A comparison of spatial interpolation methods for estimation of average electromagnetic field magnitude. Progress in Electromagnetics Research M, 14, 135, 2010.

24. FACCOLI M., STERGULC F. Ips typographus (L.) pheromone trapping in south Alps: spring catches determine damage thresholds. Journal of Applied Entomology, 128 (4), 307, 2004.

25. WESLIEN J., ANNILA E., BAKKE A., BEJER B., EIDMANN H.H., NARVESTAD K., NIKULA A., RAVN H.P. Estimating risks for spruce bark beetle (Ips typographus (L.)) damage using pheromone-baited traps and trees. Scandinavian Journal of Forest Research, 4 (1-4) 87, 1989.

26. OVERBACK M., SCHMIDT M. Modelling infestation risk of Norway spruce by Ips typographus (L.) in the Lower Saxon Harz Mountains (Germany). Forest Ecology and Management, 266, 115, 2012.

27. SCHMIDT M., HANEWINKEL M., KÄNDLER G., KUBLIN E., KOHNLE U. An inventory based approach for modeling single-tree storm damage - experiences with the winter storm of 1999 in southwestern Germany. Canadian Journal of Forest Research, 40, 1636, 2010.

28. KÄRVEMO S., VAN BOECKEL T.P., GILBERT M., GRÉGOIRE J.C., SCHROEDER M. Large-scale risk mapping of an eruptive bark beetle - Importance of forest susceptibility and beetle pressure. Forest Ecology and Management, 318, 158,2014

29. PAVEL M., WOJCIECH G., MIROSLAV B., JAROSLAV Š., VERONIKA B., RASTISLAV J. Host and site factors affecting tree mortality caused by the spruce bark beetle (Ips typographus) in mountainous conditions. Forest Ecology and Management, 331, 196, 2014.

30. AKKUZU E., SARIYILDIZ T. İklimin Ips typographus (L.)'un tuzaklanması, yoğunluğu ve zararı üzerine etkisi. 
III. Ulusal Karadeniz Ormanc1lık Kongresi, 1360-1367, 20 22 May1s, Artvin, Turkey, 2010.

31. AKKUZU E., SARIYILDIZ T. Artvin-Hatila Vadisi Milli Parkı ormanlarında Ips typographus (L.)'un etkileri, zararı etkileyen faktörler ve çözüm önerileri. Türkiye I. Orman Entomolojisi ve Patalojisi Sempozyumu, s. 20, 23-25 Kasım, Antalya, Turkey, 2011.

32. LOBINGER G., SKATULLA U. Untersuchungen zum Einfluss von Sonnenlicht auf das Schwärmverhalten von Borkenkäfern. Anzeiger für Schädlingskunde, Pflanzenschutz, Umweltschutz, 69, 183, 1996.

33. JAKUS R. A method for the protection of spruce stands against Ips typographus by the use of barriers of pheromone traps in nort-eastern Slovakia. Anzeiger für Schädlingskunde, Pflanzenschutz, Umweltschutz, 71, 152, 1998.

34. MATTSON W.J., HAACK R.A. The role of drought in outbreaks of plant-eating insects. Bioscience, 37, 110, 1987.

35. SHAVLIASHVILI I.A., BEROZASHVILI T.I. Resistance of Oriental Spruce [to pests] in relation to soil moisture and site conditions in the Borzhomi gorge [Soviet Georgia]. Sb. nauch. Rabot po izuch. bol'shogo elovogo luboeda v Gruzii, 2, 143, 1976.

36. DEMIRARSLAN K.O., AKINCI H. Doğu Karadeniz Bölgesindeki partikül madde dağılımlarının coğrafi bilgi sistemleri yardımıla belirlenmesi (Determination of particulate matter dispersion in Eastern Black Sea Region using geographical information systems). Journal of Natural Hazards and Environment, 2 (1), 30, 2016.

37. DEMIRARSLAN K.O., AKINCI H. Doğu Karadeniz Bölgesinde kükürtdioksit $\left(\mathrm{SO}_{2}\right)$ dağılımlarının coğrafi bilgi sistemleri yardımıyla belirlenmesi (Determination of sulphurdioxide $\left(\mathrm{SO}_{2}\right)$ distribution in the Eastern Black Sea Region with geographical information system). Journal of Natural Hazards and Environment, 2 (2), 81, 2016.

38. LOIBL D., LEHMKUHL F., GRIEßINGER J. Reconstructing glacier retreat since the Little Ice Age in SE Tibet by glacier mapping and equilibrium line altitude calculation. Geomorphology, 214, 22, 2014.

39. HUANG F., LIU D., TAN X., WANG J., CHEN Y., HE B. Explorations of the implementation of a parallel IDW interpolation algorithm in a Linux cluster-based parallel GIS. Computers \& Geosciences, 37, 426, 2011.

40. GONG G., MATTEVADA S., O'BRYANT S. Comparison of the accuracy of kriging and IDW interpolations in estimating groundwater arsenic concentrations in Texas. Environmental Research 130, 59, 2014. 